\title{
Isolated cilioretinal artery occlusion in a patient with hypertensive crisis
}

\author{
Sang-Uk Park, Seung-Jun Lee, Moosang Kim
}

Department of Ophthalmology, School of Medicine, Kangwon National University, Chuncheon, Korea

\section{Correspondence to} Professor Moosang Kim, kimmoo-79@hanmail.net

\section{CrossMark}

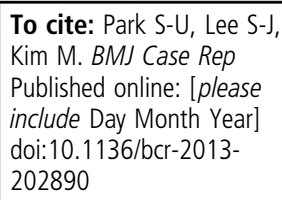

\section{DESCRIPTION}

A 35-year-old Asian man presented with acute vision loss in the right eye. On examination, the best corrected visual acuities were 20/50 in the right eye and 20/25 in the left eye. Anterior segment examination was normal, intraocular pressures were $18 \mathrm{~mm} \mathrm{Hg}$ in both eyes and there was no pupillary abnormality. Fundus examination of the right eye revealed an area of retinal papillomacular infarction with associated oedema due to cilioretinal artery occlusion illustrated on colour image and optical coherent tomography (figure 1). Fundus examination of the left eye showed multiple retinal haemorrhages with cotton wool spots (figure 2). Fluorescein angiography revealed delayed filling of the cilioretinal artery, consistent with cilioretinal artery occlusion (figure 3). Further examination revealed severe systemic hypertension (229/ $170 \mathrm{~mm} \mathrm{Hg}$ ) with a regular heart rate of $98 \mathrm{bpm}$. He was sent to the emergency room for lowering blood pressure and was admitted to cardiology to rule out secondary hypertension. Left ventricular hypertrophy was demonstrated on echocardiogram. No significant findings were identified by renal
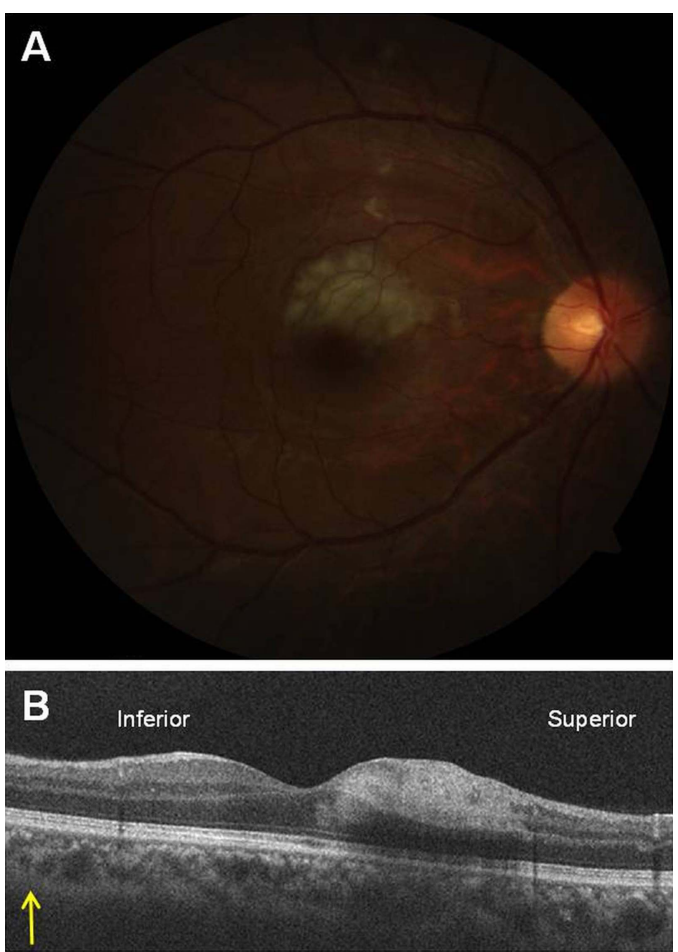

Figure 1 (A) Fundus photograph of the right eye showing superficial retinal whitening along the course of the cilioretinal artery. (B) Optical coherence tomography revealing a hyper-reflectivity of the inner retinal layers corresponding to a retinal infarction.

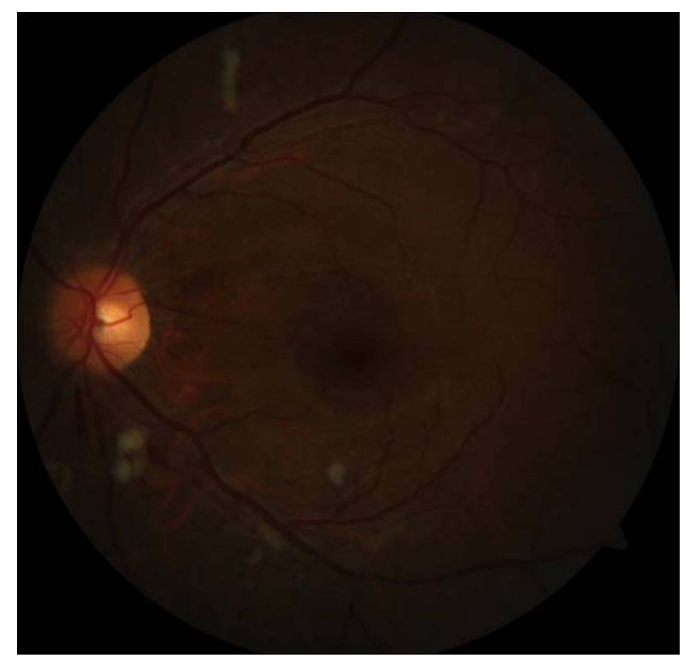

Figure 2 Fundus photograph of the left eye showing multiple retinal haemorrhages with cotton wool spots.

angiogram and brain CT. There was no evidence of secondary hypertension. After 8 weeks, retinal changes were completely resolved with improvement of vision in his right eye to 20/30.

Cilioretinal artery occlusions occur in three clinical settings: as an isolated occlusion, in association with central retinal vein occlusions and in conjunction with anterior ischaemic optic neuropathy. ${ }^{1}$ Interestingly enough, in the above case hypertensive crisis and associated retinopathy were the only clinical findings manifested with no other signs of underlying vascular occlusive disease.

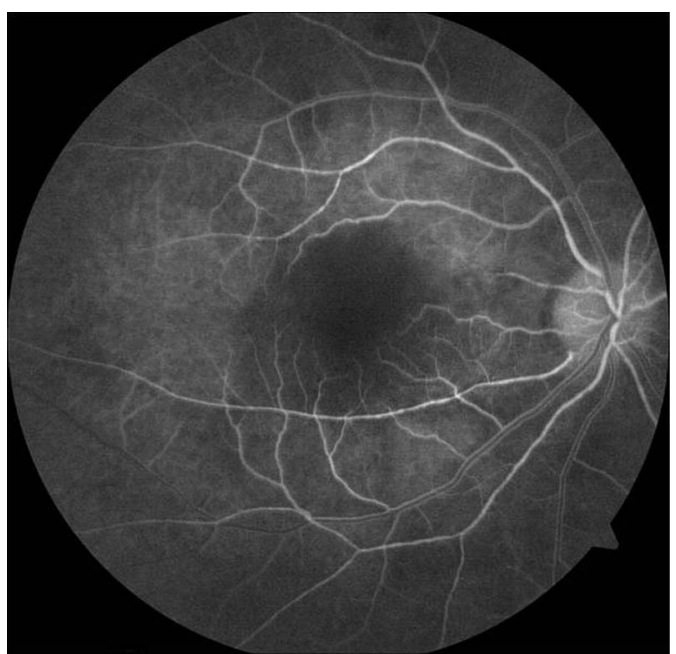

Figure 3 Fluorescein angiography demonstrating poor filling of the obstructed cilioretinal artery and retinal capillary non-perfusion within the area of distribution of the vessel. 


\section{Learning points}

- Isolated occlusion of the cilioretinal artery is a rare entity as it typically presents in association with central retinal artery or vein occlusion.

- Although diagnosis of isolated cilioretinal artery occlusion is made without difficulty, the underlying pathogenic mechanism remains difficult to explain due to the various phenomena revealed by the increased arterial pressure.
Contributors S-UP, S-JL and MK treated the patient and in doing so acquired the case data. They were also involved in the drafting of the manuscript. All the authors read and approved the final version of the manuscript.

Competing interests None.

Patient consent Obtained.

Provenance and peer review Not commissioned; externally peer reviewed.

\section{REFERENCE}

1 Brown GC, Moffat K, Cruess A, et al. Cilioretinal artery obstruction. Retina 1983;3:182-7.

Copyright 2014 BMJ Publishing Group. All rights reserved. For permission to reuse any of this content visit http://group.bmj.com/group/rights-licensing/permissions.

BMJ Case Report Fellows may re-use this article for personal use and teaching without any further permission.

Become a Fellow of BMJ Case Reports today and you can:

- Submit as many cases as you like

- Enjoy fast sympathetic peer review and rapid publication of accepted articles

- Access all the published articles

- Re-use any of the published material for personal use and teaching without further permission

For information on Institutional Fellowships contact consortiasales@bmjgroup.com

Visit casereports.bmj.com for more articles like this and to become a Fellow 